\title{
8. GEOCHEMICAL EFFECTS OF ALTERATION ON MAFIC ROCKS FROM INDIAN OCEAN SITE 706 ${ }^{1}$
}

\author{
John D. Greenough, ${ }^{2}$ Brian J. Fryer, ${ }^{3}$ and Paul T. Robinson ${ }^{4}$
}

\begin{abstract}
Highly vesicular and glassy pillow basalts from the sunken oceanic island at Ocean Drilling Program Site 706 in the Indian Ocean show variable alteration and the addition of secondary zeolite facies clay minerals. The mineralogical changes reflect chemical additions of $\mathrm{K}, \mathrm{Rb}, \mathrm{Cs}, \mathrm{Li}, \mathrm{Si}, \mathrm{Sc}, \mathrm{Fe}$, and possibly $\mathrm{Sr}, \mathrm{Pb}, \mathrm{Tl}, \mathrm{Au}, \mathrm{Pt}$, and $\mathrm{Rh}$. The elements $\mathrm{Ca}, \mathrm{Mg}, \mathrm{Mn}, \mathrm{Ni}$, and possibly $\mathrm{Na}, \mathrm{Ba}, \mathrm{U}$, and $\mathrm{Ir}$ were removed, but the rare earth elements as well as the elements $\mathrm{Zr}$, $\mathrm{Nb}, \mathrm{Y}, \mathrm{Ti}, \mathrm{Al}, \mathrm{V}, \mathrm{Th}$, and probably $\mathrm{P}$ and $\mathrm{Hf}$ were immobile. The data for $\mathrm{Cr}, \mathrm{Cu}, \mathrm{Zn}, \mathrm{Bi}, \mathrm{Pd}$, and $\mathrm{Ru}$ show large variations, indicating that they were probably mobile; whether they were generally added or removed could not be ascertained, however.

The chemical additions and removals are similar to the low-temperature changes observed in ocean-floor basalts near the seawater-seafloor interface. The large, though nonpervasive, chemical changes reflect the effects of alteration caused by seawater percolating down through easily altered glass-rich basalts. They imply that a low-temperature alteration zone similar to the zone in the recharge portion of the ocean-floor (ridge) hydrothermal system also occurs on oceanic islands.
\end{abstract}

\section{INTRODUCTION}

In recent years numerous studies of altered mafic volcanic rocks have shown that most, if not all, elements can be added or subtracted from a rock during low-temperature metamorphism (metasomatism). Even such "immobile" elements as $\mathrm{Zr}$ and $\mathrm{Nb}$ can be affected under appropriate conditions (e.g., Hellman et al., 1979; Hynes, 1980). Specific element behavior is dependent on an element's concentration in the rock, on its concentration in solutions entering the rock, and on partitioning between the fluid phase (which can be highly variable in composition) and the low-temperature secondary minerals that are stable in the rock in question. Given these variables, the effects of low-temperature metamorphic processes are difficult to predict. Nevertheless, in general, alteration processes on the ocean floor yield somewhat consistent chemical changes that permit comparisons and act as predictors in new studies (e.g., Frey et al., 1974; Mottl, 1983).

The purpose of this study is to document quantitatively the effects of alteration on Ocean Drilling Program (ODP) Site 706 hotspot basalts (Fig. 1) from a sunken oceanic island in the Indian Ocean. These rocks are particularly conducive to such a study because they show a range of mineralogical alteration effects. Furthermore, the basalts form distinct groups (flows?) according to their gross geochemical characteristics and depth in the hole, such that chemical variations within each group can be related to alteration processes. It will be shown that there are numerous similarities between alteration effects in these oceanic-island basalts and the chemical changes that occur in the low-temperature alteration zone of the ocean floor.

\footnotetext{
${ }^{1}$ Duncan, R. A., Backman, J., Peterson, L. C., et al., 1990. Proc. ODP, Sci. Results, 115: College Station, TX (Ocean Drilling Program).

2 Geology Department, Mount Allison University, Sackville, New Brunswick, Canada, EOA $3 \mathrm{CO}$.

${ }^{3}$ Department of Earth Sciences, Memorial University of Newfoundland, St. John's, Newfoundland, Canada, A1B 3X5.

4 Centre for Marine Geology, Dalhousie University, Halifax, Nova Scotia, Canada, B3H $3 \mathrm{~J} 5$.
}

\section{SAMPLE INFORMATION}

Basalts drilled during Leg 115 represent the products of oceanic-island volcanism associated with the Réunion hotspot trace. Sedimentary rocks overlying Site 706 basalts (Fig. 1) were dated paleontologically as early Oligocene (Backman, Duncan, et al., 1988 ) and radiometrically at $33 \mathrm{Ma}$ (Duncan and Hargraves, this volume). The basalts were erupted at a time when the hotspot coincided with the Central Indian Ridge (Fisk et al., 1989).

Shipboard petrographic descriptions and X-ray fluorescence (XRF) data were used to select samples that showed a range of alteration effects. The samples used in this study come from Core 115-706A-6H and Cores 115-706C-2R through -8R; sample numbers (location numbers) are given in Table 1. All samples come from depths $<120 \mathrm{~m}$ below the seafloor (mbsf).

Petrographically, the basalts used in this study (Backman, Duncan, et al., 1988) contain zoned plagioclase $(\sim 15 \%, 0.5$ $\mathrm{mm}$ ) and purplish, locally glomeroporphyritic, augite microphenocrysts as well as olivine microphenocrysts $(1 \%-2 \%)$ that are entirely altered to clay minerals. The fine-grained to glassy (devitrified) matrix consists of radiating clinopyroxene and $\mathrm{Fe}-$ Ti oxide crystals that indicate quenching. The basalts are vesicular to highly vesicular $(5 \%-20 \%)$, and most vesicles are filled with secondary minerals. The alteration phases, which are dominated by clay minerals (celadonite?), also replace glass and matrix minerals and make up $10 \%-50 \%$ of each sample. The abundance of glassy contacts suggests that these are pillow basalts, and their highly vesicular nature indicates that they were erupted at shallow water depths.

\section{SAMPLE PREPARATION AND ANALYTICAL PROCEDURES}

Powders were prepared on board JOIDES Resolution by selecting fairly alteration-free portions of the core and then abrading the cut surfaces on a diamond lap. Samples were cleansed in an ultrasound with methanol and distilled water, crushed in a hydraulic press, and powdered in a tungsten-carbide mill. Despite the attempt to avoid highly altered material (the samples were initially selected for analysis of the primary magmatic geochemistry), it became apparent that a few of the samples showed rather extreme alteration effects. 


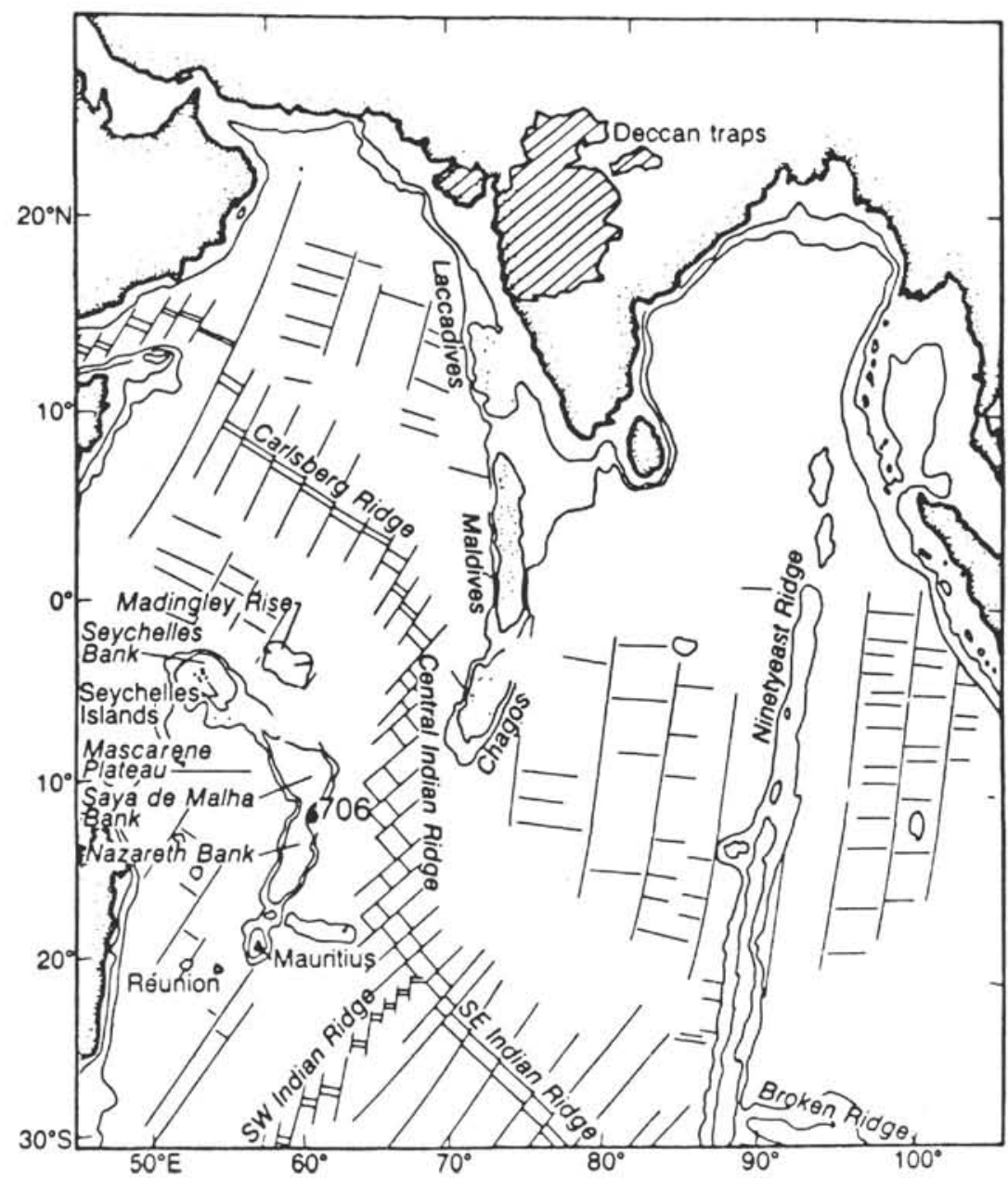

Figure 1. Location map for Site 706 in the Indian Ocean (modified from Duncan et al., 1989).

Table 1. Sample numbers for Site 706 basalts used in this study.

\begin{tabular}{clc}
\hline Group & \multicolumn{1}{c}{$\begin{array}{c}\text { Core, section, } \\
\text { interval (cm) }\end{array}$} & $\begin{array}{c}\text { Sample } \\
\text { code } \\
\text { letter }\end{array}$ \\
\hline 1 & $115-706 \mathrm{~A}-6 \mathrm{H}-\mathrm{CC}, 21-23$ & $\mathrm{~A}$ \\
1 & $115-706 \mathrm{C}-2 \mathrm{R}-2,28-30$ & $\mathrm{~B}$ \\
1 & $115-706 \mathrm{C}-2 \mathrm{R}-2,74-77$ & $\mathrm{C}$ \\
1 & $115-706 \mathrm{C}-2 \mathrm{R}-2,142-146$ & $\mathrm{D}$ \\
1 & $115-706 \mathrm{C}-3 \mathrm{R}-1,83-85$ & $\mathrm{E}$ \\
1 & $115-706 \mathrm{C}-3 \mathrm{R}-2,45-47$ & $\mathrm{~F}$ \\
2 & $115-706 \mathrm{C}-4 \mathrm{R}-1,78-80$ & $\mathrm{G}$ \\
2 & $115-706 \mathrm{C}-4 \mathrm{R}-2,116-119$ & $\mathrm{H}$ \\
2 & $115-706 \mathrm{C}-5 \mathrm{R}-1,82-84$ & $\mathrm{I}$ \\
2 & $115-706 \mathrm{C}-5 \mathrm{R}-2,52-56$ & $\mathrm{~J}$ \\
2 & $115-706 \mathrm{C}-5 \mathrm{R}-2,135-137$ & $\mathrm{~K}$ \\
2 & $115-706 \mathrm{C}-5 \mathrm{R}-3,59-62$ & $\mathrm{~L}$ \\
2 & $115-706 \mathrm{C}-6 \mathrm{R}-1,45-50$ & $\mathrm{M}$ \\
2 & $115-706 \mathrm{C}-6 \mathrm{R}-2,17-19$ & $\mathrm{~N}$ \\
3 & $115-706 \mathrm{C}-8 \mathrm{R}-1,32-35$ & $\mathrm{O}$ \\
3 & $115-706 \mathrm{C}-8 \mathrm{R}-1,67-77$ & $\mathrm{P}$ \\
3 & $115-706 \mathrm{C}-8 \mathrm{R}-2,44-48$ & $\mathrm{Q}$ \\
3 & $115-706 \mathrm{C}-8 \mathrm{R}-2,125-128$ & $\mathrm{R}$ \\
3 & $115-706 \mathrm{C}-8 \mathrm{R}-3,45-48$ & $\mathrm{~S}$ \\
\hline
\end{tabular}

Note: Sample code letters are those used in the text and figures.
Major element data and the data for the trace elements $\mathrm{Cr}$, $\mathrm{Ni}, \mathrm{Zn}, \mathrm{Cu}, \mathrm{Y}, \mathrm{Zr}, \mathrm{Nb}, \mathrm{Rb}, \mathrm{Sr}, \mathrm{Ba}$, and $\mathrm{V}$ were collected by means of the XRF facilities on board JOIDES Resolution and are reported in Backman, Duncan, et al. (1988). The analyses for $\mathrm{Au}, \mathrm{Pd}, \mathrm{Pt}, \mathrm{Rh}, \mathrm{Ru}$, and Ir were carried out at The Memorial University of Newfoundland (MUN) with inductively coupled plasma-mass spectrometry (ICP-MS) equipment and procedures as reported in Greenough and Fryer (this volume). The data for $\mathrm{Li}, \mathrm{Sc}, \mathrm{Cs}, \mathrm{Hf}, \mathrm{Tl}, \mathrm{Pb}, \mathrm{Bi}$, Th, U, and rare earth elements (REE) represent unpublished analyses determined with ICP-MS techniques at MUN.

\section{APPROACH}

Before alteration effects on the basalts can be discussed, a number of problems must be resolved: (1) primary variations in composition must be distinguished from variations caused by secondary processes; (2) rocks best representing the primary composition(s) must be identified and a measure of the alteration effects determined; and (3) volume changes associated with alteration must be taken into account.

Ideally, in assessing chemical changes caused by alteration, least-altered samples should only be compared with altered samples that have initial (unaltered) compositions identical with those of unaltered rocks. Unfortunately, the initial compositions of single lava flows are rarely homogeneous because of a variety of posteruption processes (Basaltic Volcanism Study Proj- 
ect, 1981, p. 117). Primary interflow variations in composition can be caused by numerous pre-eruption petrogenetic processes. Rapid cooling of Site 706 pillow basalts helped limit in-situ differentiation. Nevertheless, lavas from different flows must be identified, and anomalous samples that may represent the local effects of primary differentiation processes must be recognized.

The basalts used in this study were divided into three convenient groups on the basis of (1) depth in the hole and (2) marked variations in geochemistry (Fig. 2). Group 1 basalts (six samples studied) come from between 30 and $60 \mathrm{mbsf}$ and have the lowest average $\mathrm{MgO}$ contents $(\sim 5.0 \mathrm{wt} \%)$. Three other samples from this interval, two with higher $\mathrm{MgO}$ contents (5.7 and $6.1 \mathrm{wt} \%$ ) and one with a lower $\mathrm{MgO}$ content $(4.2 \mathrm{wt} \%)$, were not used because we could not eliminate the possibility that their compositions reflected primary variations in geochemistry. Group 2 basalts (eight samples) occur between 60 and 90 mbsf and show higher average $\mathrm{MgO}$ contents $(\sim 5.8 \mathrm{wt} \%)$ than Group 1 basalts. Group 3 basalts (five samples) occur at depths of about $100 \mathrm{mbsf}$ and contain $\mathrm{MgO}$ contents similar to those of Group 2. However, they have by far the highest $\mathrm{Cr}$ contents $(\sim 100$ ppm) of all basalts retrieved at Site $706(\mathrm{Cr}=\leq 40 \mathrm{ppm}$ in all other basalts).

Basalts recovered from the bottom of the hole ( $\sim 110 \mathrm{mbsf})$ show $\mathrm{TiO}_{2}$ contents of approximately $1.2 \mathrm{wt} \%$, less than half the concentration in all other rocks. These rocks were not used in this study because only three samples were available for study.
Some of the compositional variation within each group, such as demonstrated by $\mathrm{MgO}$ content (Fig. 2), may be primary although there is no correlation between $\mathrm{MgO}$ and elements commonly considered "immobile" (such as Zr; Pearce and Cann, 1973; Floyd and Winchester, 1975). As discussed below, elements such as $\mathrm{Rb}$ show large variations in concentration that display no relationship to $\mathrm{Zr}$ concentrations and are almost certainly related to alteration processes. For the sake of discussion, we make the assumption that samples within each group had identical prealteration compositions.

Various indexes of alteration include the modal percentages of secondary minerals, the degree of hydration (i.e., loss on ignition [LOI]; Greenough and Papezik, 1985), and such alteration-sensitive elements as $\mathrm{K}$ or $\mathrm{Rb}$. The nonpervasive nature of alteration in Site 706 lavas makes quantification of the degree of alteration from modal mineralogy difficult because the percentages of secondary minerals observed in thin section may not correspond with the percentages in the sample materials analyzed. The LOI values are generally quite low $(<1 \mathrm{wt} \%)$ in the basalts, and they show no relationship to the large variations in other geochemical parameters (such as Rb concentrations) that must be a result of alteration processes.

Inspection of the geochemical data presented in Backman, Duncan, et al. (1988) reveals that one of the most obvious effects of alteration is highly variable $\mathrm{Rb}$ values within each sample group (e.g., concentrations range from 4 to $43 \mathrm{ppm}$ in Group

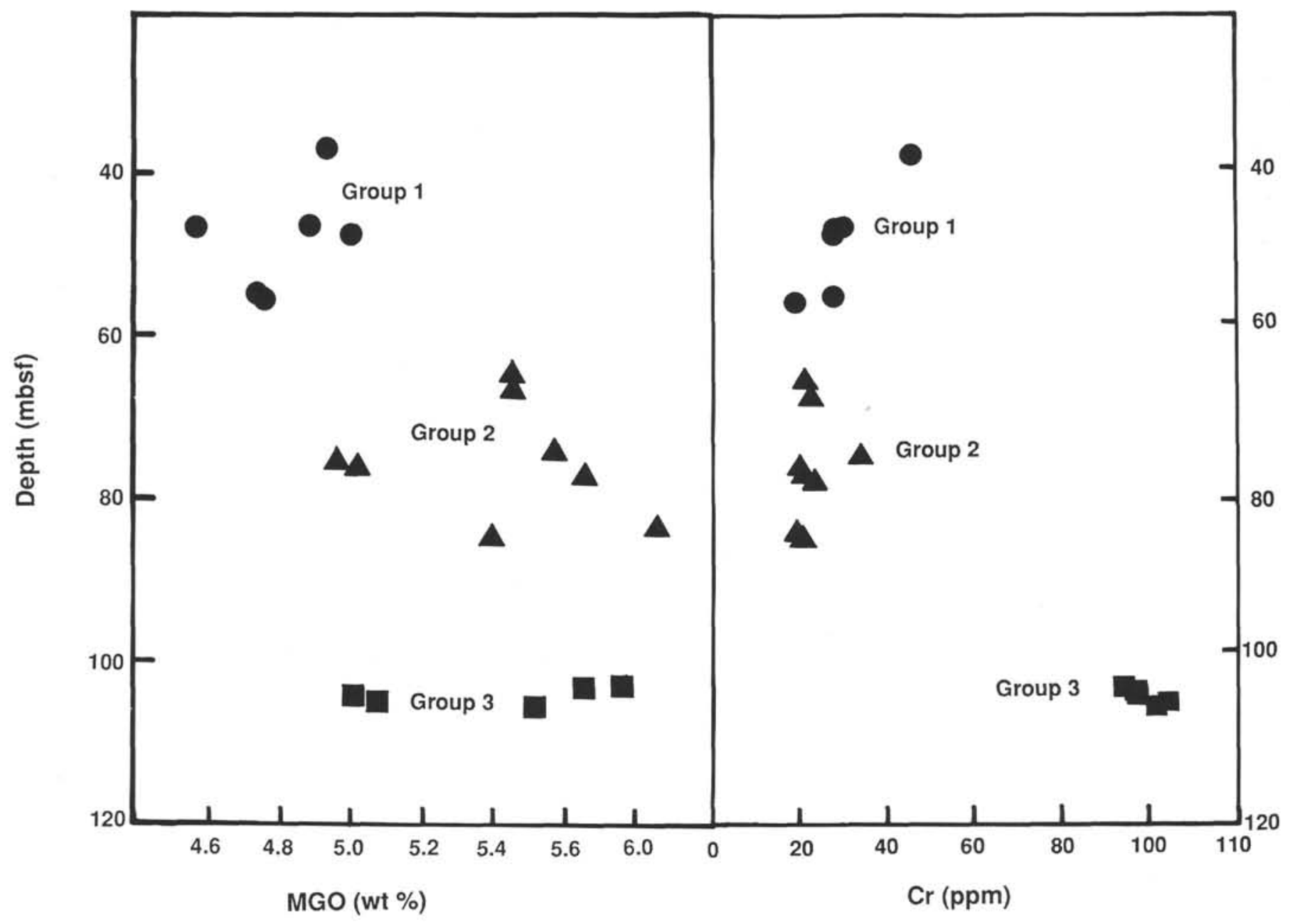

Figure 2. Plots of $\mathrm{MgO}(\mathrm{wt} \%)$ and $\mathrm{Cr}(\mathrm{ppm})$ vs. sub-bottom depth (mbsf) for Site 706 basalts used in this study. The plot permits subdivision of the basalts into three groups. 
2 basalts). These variations cannot be accounted for in terms of primary processes because the concentrations of most major elements remain fairly constant (although there are small variations in the major element chemistry within each group that may be related to alteration). The growth of clay minerals (celadonite) would be expected to raise the levels of both $\mathrm{K}_{2} \mathrm{O}$ and $\mathrm{Rb}$. Therefore, we assume that $\mathrm{Rb}$ is an alteration-sensitive element and that samples with the lowest $\mathrm{Rb}$ values in each group represent the least-altered samples.

Gresens (1967) showed that in determining chemical changes related to alteration it is necessary to account for volume changes in the rock. The effects of volume changes can be eliminated if it is known that some element was immobile during alteration. Additions and subtractions of all other elements can be assessed by comparing the mobile element/immobile element ratios in altered rocks with the same ratios in the least-altered samples (Gresens, 1967).

To identify elements that may have been immobile, we begin with Gresens's (1967) equation:

$$
f_{V}\left(g^{B} / g^{A}\right) C^{B}{ }_{n}-C^{A}{ }_{n}=X_{n},
$$

where $f_{V}=$ the volume factor; $g^{A}=$ the specific gravity of the parent rock; $g^{B}=$ the specific gravity of the altered rock; $C^{A}{ }_{n}$ $=$ the concentration of component $n$ in the parent rock; $C^{B}{ }_{n}=$ concentration of component $n$ in the altered rock; and $X_{n}^{n}=$ amount of component $n$ lost or gained.

The equation was solved for $f_{V}$ assuming that $g^{A}=g^{B}$ and $X_{n}=0$, and that samples with the lowest Rb (A, H, and S for Groups 1, 2, and 3, respectively) are the least altered and that those with the highest $\mathrm{Rb}(\mathrm{C}, \mathrm{K}$, and $\mathrm{Q})$ are the most altered. The resulting volume factors ( $f_{V}$ values) represent the volume changes necessary to account for zero loss or gain of each element; they have been plotted in Figure 3. Elements with high $f_{V}$ values were most likely lost during alteration and those at low values probably gained. Because specific gravities were not used in the calculations, the absolute $f_{V}$ values are not known. However, the relative positions of elements across the graph are accurate.

The elements likely to be least mobile plot in the middle of the data cluster because this zone requires the smallest addition or removal of the maximum number of elements. For each of the three groups of Site 706 lavas, this corresponds to an $f_{V}$ value of about 1 (Fig. 3 ) and numerous elements appear to have been fairly immobile. For all rocks, $\mathrm{Zr}$ plots very close to the center of the data points ( $f_{V}$ values of $1.03,1.03$, and 1.04 for Groups 1, 2, and 3, respectively). For this reason and because $\mathrm{Zr}$ is commonly considered immobile under low-grade metamorphic conditions (Pearce and Cann, 1973; Floyd and Winchester, 1975), we assume that $\mathrm{Zr}$ was immobile and use it in evaluating the mobility of all other elements as described below.

Figure 4 illustrates the percentage change between element/ $\mathrm{Zr}$ ratios in altered rocks as compared to fresh rocks (i.e., lowest $\mathrm{Rb}$ ). Three sets of graphs are illustrated, one for each group of rocks. Positive values on the $\mathrm{Y}$ axis indicate that an element was added to the rock during alteration, whereas negative values imply that the element was removed. To accommodate the large percentage changes for some elements, a logarithmic scale was used with the axis broken at 1 and -1 so that positive and negative percentage changes could be plotted. Changes of $<1 \%$ were plotted on the 0 line. The percentage changes are plotted vs. absolute $\mathrm{Rb}$ concentrations, which are taken as a measure of the amount of alteration in each sample (samples are labeled B, C, D, etc., across the top of the graphs; see Table 1 for sample identification). The Rb concentration in the least-altered sample for each group (which is the sample all other samples in the group are compared with) is given by the position of samples labeled $\mathrm{A}, \mathrm{H}$, and $\mathrm{S}$ across the top of the graphs.

The data are organized according to the geochemical characteristics of the elements. Alkaline earth and alkali metals, as well as Th and U, appear in the plots marked A1, B1, and C1, which contain the data for Groups 1, 2, and 3, respectively. Plots marked A2, B2, and C2 contain elements with typically high valences and/or elements that are commonly considered immobile. Plots marked 3 display rare earth element data; those labeled 4, siderophile and chalcophile elements; and noble metal data are given in diagrams at the far right (A5, B5, and C5).

In interpreting the graphs, emphasis is placed on answers to the following questions:

1. Does the most-altered sample show a decrease or increase (or neither) in concentration for a particular element (as indicated by element $/ \mathrm{Zr}$ ratios) relative to the least-altered sample?

2. Are there overall increasing or decreasing trends shown by the altered samples regardless of whether the concentrations begin (at lowest $\mathrm{Rb}$ ) or end (at highest $\mathrm{Rb}$ ) higher or lower than in the least-altered sample? For example, an element might show a decreasing trend with increasing $\mathrm{Rb}$ in altered samples even though all samples may actually show higher concentrations of the element than the least-altered sample.

3. Do all three groups of data show the same tendencies for a particular element with regard to Questions 1 and 2?

\section{DATA PRESENTATION}

The alkali metals $\mathrm{Cs}, \mathrm{K}$, and $\mathrm{Li}$ (and, by assumption, $\mathrm{Rb}$ ) exhibits the most consistent behavior (Figs. 4A1, 4B1, and 4C1). In general, $\mathrm{Cs}$ shows the greatest percentage enrichment, with $\mathrm{Rb}, \mathrm{K}$, and $\mathrm{Li}$ displaying lesser amounts of enrichment (in that order) at any particular degree of alteration. Furthermore, the percentage enrichment of each element increases regularly with the degree of alteration. Both $\mathrm{Mg}$ and $\mathrm{Ca}$ appear to have been removed with alteration, as shown by negative percentage changes for the most-altered sample in each group. The behavior of $\mathrm{Sr}, \mathrm{Na}, \mathrm{Ba}$, and $\mathrm{U}$ is not clear, although the most-altered samples in two of three groups indicate that concentrations decrease with alteration for the latter three elements. Thorium appears to have been immobile.

The flat patterns for $\mathrm{Ti}, \mathrm{Nb}, \mathrm{Al}$, and $\mathrm{V}$ and the low percentage changes $(<5 \%)$ indicate that these elements were immobile (Figs. 4A2, 4B2, and 4C2). Flat patterns for $\mathrm{Y}$ imply that it was also immobile. By definition, the pattern for $\mathrm{Zr}$ is flat, and all data points show zero change from parental concentrations. Values for Sc are only available for rock Groups 2 and 3 (lower two graphs). In both cases, the most-altered sample shows slightly higher Sc values than the least-altered sample and poor positive trends are indicated, thus implying a slight $\mathrm{Sc}$ addition. Silicon addition is indicated by positive concentration changes between least- and most-altered samples as well as by positive data trends. Values for $\mathrm{Hf}$ and $\mathrm{P}$ display inconsistent behavior between rock groups.

Flat patterns and small (generally $<10 \%$ ) concentration changes between least- and most-altered samples indicate that the REE were immobile (Figs. 4A3, 4B3, and 4C3). In two out of three groups, Mn and Ni values tend to show negative trends, and the most-altered sample generally displays the lowest concentrations of these elements, indicating removal during alteration (Figs. 4A4, 4B4, and 4C4). In Group 2, Fe shows a weak positive trend, and in all groups the most-altered sample has a higher Fe concentration than the least-altered sample, implying that $\mathrm{Fe}$ was added. The $\mathrm{Pb}$ and $\mathrm{Tl}$ patterns are erratic, but both elements may have been added since the most-altered sample in each group shows the highest concentrations. Erratic patterns 
fv
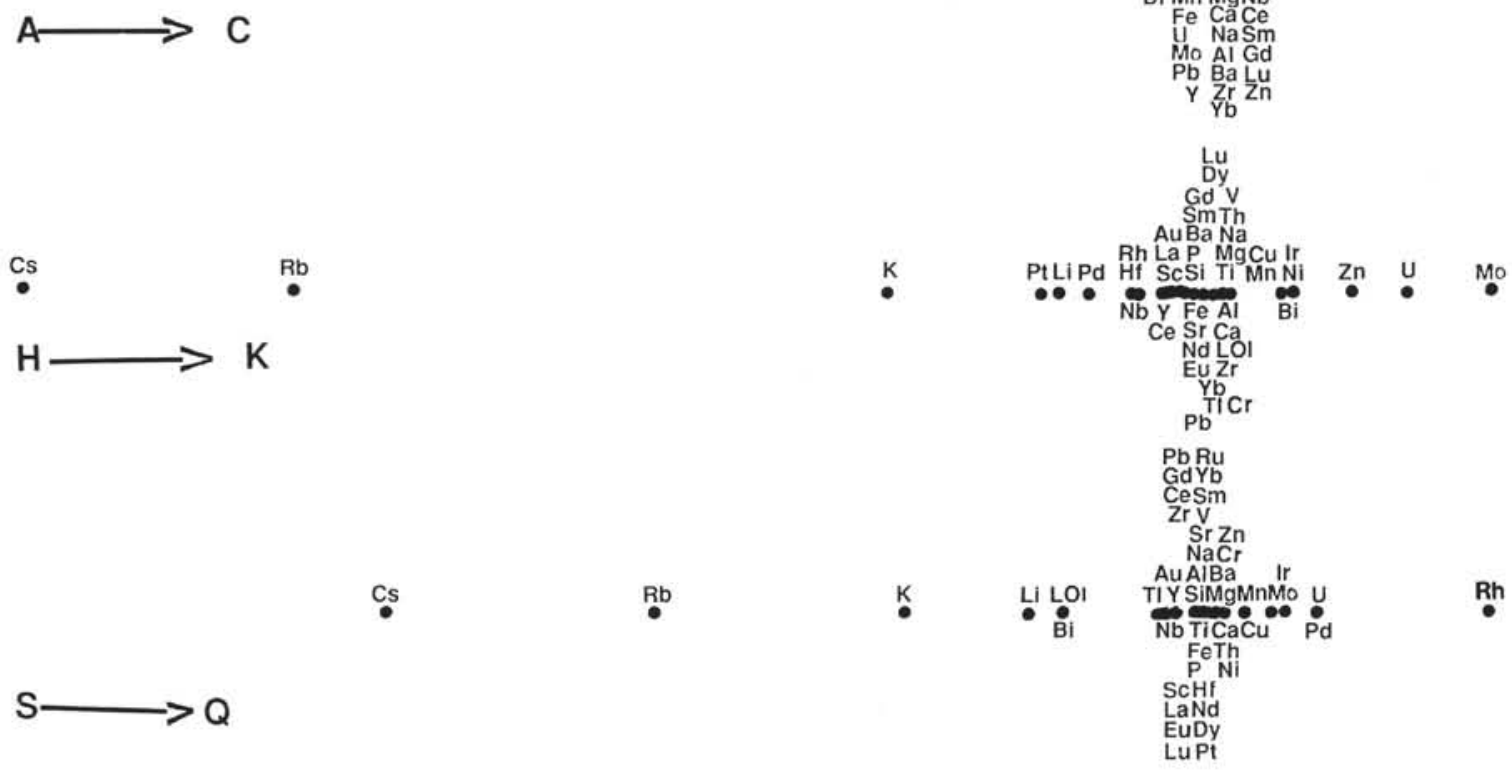

Figure 3. Volume factor $\left(f_{V}\right)$ diagram for the most-altered rock sample in each Site 706 rock group. The diagram shows the volume change necessary to account for zero loss or gain of each element in altered Samples C, K, and Q (Groups 1, 2, and 3, respectively), assuming that Samples A, H, and K represent the parent rocks, respectively. See text for discussion.

for $\mathrm{Cr}, \mathrm{Cu}, \mathrm{Zn}$, and $\mathrm{Bi}$ and inconsistent behavior between sample groups make conclusions regarding the behavior of these elements impossible.

Patterns for the noble metals (Figs. 4A5, 4B5, and 4C5) also tend to be erratic, but $\mathrm{Au}$ and $\mathrm{Pt}$ appear to have been added in two out of three groups, as shown by the positive data trends and higher concentrations in the most-altered samples than in the least-altered samples. Similarly, $\mathrm{Rh}$ addition is probable, but only Group 1 shows a positive trend. Iridium may have been removed since the most-altered sample in each group shows a lower concentration than the least-altered sample. Conclusions cannot be drawn from the $\mathrm{Pd}$ and $\mathrm{Ru}$ data.

In summary, $\mathrm{K}, \mathrm{Rb}, \mathrm{Cs}, \mathrm{Li}, \mathrm{Si}, \mathrm{Sc}, \mathrm{Fe}, \mathrm{Au}, \mathrm{Pt}$, and possibly $\mathrm{Sr}, \mathrm{Pb}, \mathrm{Tl}$, and $\mathrm{Rh}$ appear to have been added during alteration. The REE, $\mathrm{Zr}, \mathrm{Nb}, \mathrm{Y}, \mathrm{Ti}, \mathrm{Al}, \mathrm{V}$, and $\mathrm{Th}$ were immobile. $\mathrm{Ca}, \mathrm{Mg}$, $\mathrm{Mn}, \mathrm{Ni}$, and possibly $\mathrm{Na}, \mathrm{Ba}, \mathrm{U}$, and $\mathrm{Ir}$ were removed. Conclusions cannot be drawn for $\mathrm{P}, \mathrm{Hf}, \mathrm{Cr}, \mathrm{Cu}, \mathrm{Zn}, \mathrm{Bi}, \mathrm{Pd}$, and $\mathrm{Ru}$.

\section{DISCUSSION}

The behavior of many elements during the reaction of seawater with ocean-floor basalt in thermally driven, high-temperature convection systems at the mid-ocean ridges is well established as a result of studies of actual basalt samples as well as from laboratory experiments (Mottl and Holland, 1978; Mottl et al., 1979; Mottl, 1983; Seyfried et al., 1988). These investigations show that, in general, $\mathrm{Mg}$ and $\mathrm{Fe}$ were added and $\mathrm{Si}, \mathrm{Ca}$,
$\mathrm{Na}, \mathrm{Sr}, \mathrm{K}$, and $\mathrm{Mn}$ were removed as alteration took place. Similar results were also found for chlorite-forming reactions in other geologic environments (Greenough and Papezik, 1985). Of the elements listed above, only $\mathrm{Fe}, \mathrm{Mn}$, and $\mathrm{Na}$ behaved in the same way in Site 706 basalts where predominantly clay minerals (celadonite) formed.

Alteration effects in Site 706 basalts are similar to those resulting from low-temperature alteration of ocean-floor basalt and basaltic glass near the seawater-seafloor interface. Frey et al. (1974) concluded that $\mathrm{Li}, \mathrm{K}, \mathrm{Rb}, \mathrm{Cs}, \mathrm{Ba}, \mathrm{Sr}$, and $\mathrm{U}$ are added and $\mathrm{Na}, \mathrm{Ca}, \mathrm{Mg}, \mathrm{Mn}$, and $\mathrm{Si}$ are removed through the formation of clay minerals. Through studies of ophiolitic basalts as well as ocean-floor basalts, Gillis and Robinson (1985, 1988 , in press) found that similar chemical changes characterized the low-temperature alteration zone $\left(\leq 100^{\circ} \mathrm{C}\right)$ of the oceanic crust. Of the elements listed above, only $\mathrm{Si}$ and possibly $\mathrm{Ba}$ and $U$ differ from the behavior of elements in Site 706 basalts.

Elements such as Ti, Al, P, Zr, Y, Nb, and Sc commonly remain immobile under low-grade metamorphic conditions in many geologic environments (Pearce and Cann, 1973; Floyd and Winchester, 1975; Winchester and Floyd, 1977). They can be mobile, however, under appropriate conditions (e.g., high $\mathrm{CO}_{2}$ or $\mathrm{F}$ in fluid phase) (Hellman et al., 1979; Hynes, 1980; Greenough and Papezik, 1985). With regard to ocean-floor basalts in the high-temperature (Mottl, 1983) and low-temperature (Frey et al., 1974) portions of the hydrothermal system, it can 


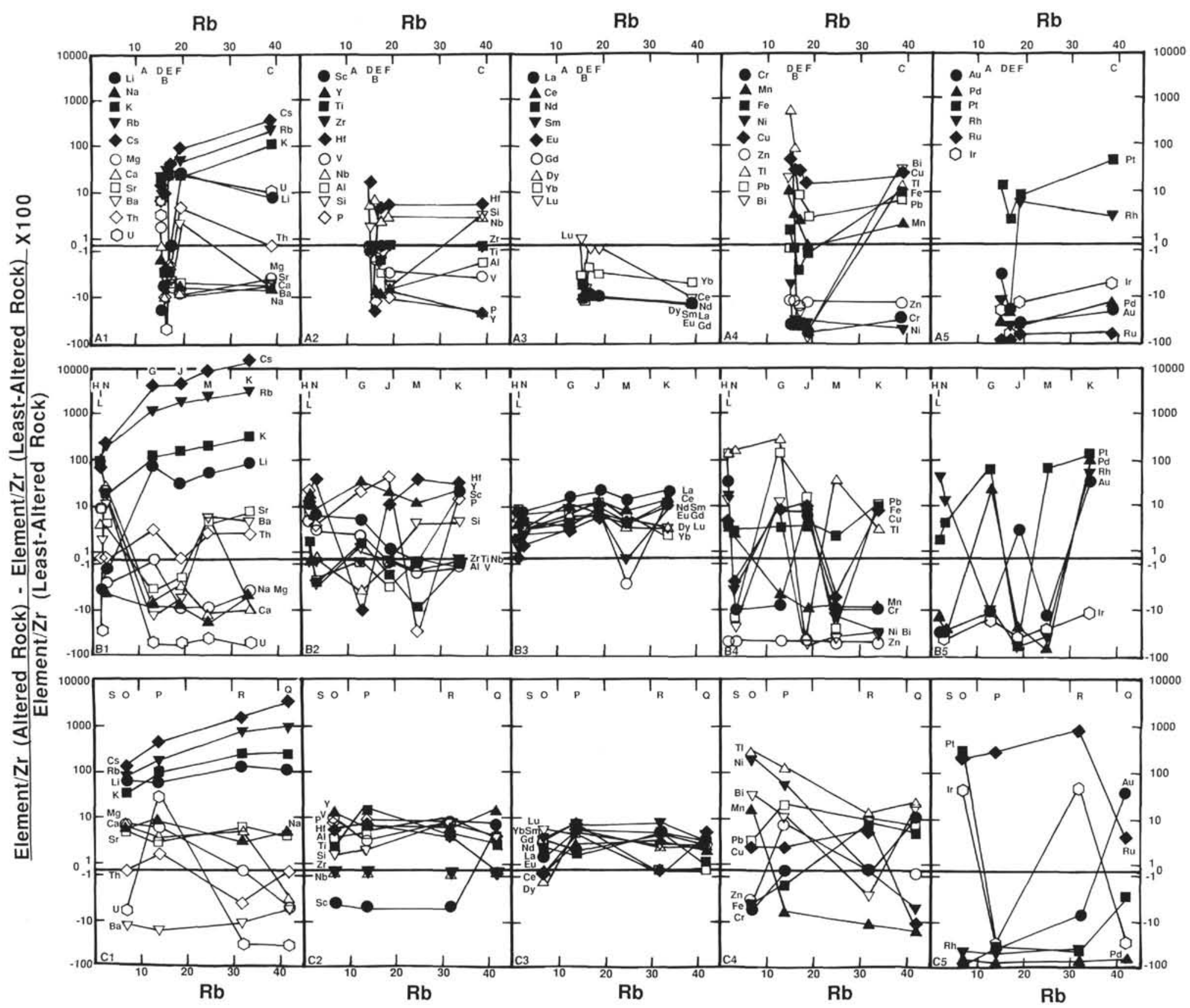

Figure 4. Graphs showing the effect of increasing alteration on element concentrations in Group 1 (upper plots), 2 (middle), and 3 (lower) basalts. The absolute Rb concentration (ppm) on the $\mathrm{X}$ axis acts as a measure of alteration. The percentage change (positive or negative) between element $/ \mathrm{Zr}$ ratios in parental rocks and element $/ \mathrm{Zr}$ ratios in altered rocks appears on the $\mathrm{Y}$ axis. See text for discussion. 
be shown that $\mathrm{Sc}, \mathrm{Y}, \mathrm{Ti}, \mathrm{Zr}, \mathrm{Hf}, \mathrm{V}, \mathrm{Nb}, \mathrm{Al}$, and $\mathrm{P}$ remain immobile for the most part. Site 706 basalts show analogous behavior for these elements.

Rare earth element mobility in basaltic rocks is well documented for a number of geologic environments (Floyd, 1977; Hellman et al., 1979; Nyström, 1984), including the ocean floor. Glass tends to be more significantly affected than crystalline basalt (Frey et al., 1974). Alteration generally raises light REE concentrations, with some rocks showing a positive $\mathrm{Ce}$ anomaly on chondrite-normalized diagrams. Immobility of REE in Site 706 basalts contrasts with what is normally observed.

It is well known that $\mathrm{Cu}$ is highly mobile during zeolite facies metamorphism of basalts (e.g., Papezik et al., 1988). During low-grade metasomatism of ocean-floor basalts, $\mathrm{Cr}$ and $\mathrm{Ni}$ are either immobile or slightly removed whereas $\mathrm{Cu}$ and $\mathrm{Pb}$ tend to be added and $\mathrm{Zn}$ removed (Frey et al., 1974; Mottl, 1983). Our conclusions for $\mathrm{Ni}$ and $\mathrm{Pb}$ agree with these findings; in general, however, all the elements in this group (i.e., $\mathrm{Cu}, \mathrm{Zn}, \mathrm{Tl}$, and $\mathrm{Bi}$ ) behaved incoherently. Nevertheless, the large losses and gains in some elements (e.g., $\mathrm{Bi}$ and $\mathrm{Tl}$ ) imply that many of these elements were extremely mobile. The erratic patterns suggest that movement of these elements was decoupled from the alteration processes that most clearly affected the alkali metals. In other words, $\mathrm{Rb}$ concentrations act as a poor indicator of the effects of alteration on the sulfide phases that might be expected to harbor these elements.

Many studies have indicated that, with the exception of gold, the noble metals are immobile during low-grade alteration. For example, Watkinson and Dunning (1979) and Oshin and Crocket (1982) concluded that intense serpentinization of various mafic and ultramafic rocks in central Canada resulted in little (or only local) centimeter-scale Pt, Pd, or Ir mobility. Nevertheless, recognizing that some platinum-group-element (PGE) ore deposits dominated by $\mathrm{Pt}, \mathrm{Pd}$, and $\mathrm{Rh}$ are of hydrothermal or diagenetic/epithermal origin (e.g., New Rambler deposit, Wyoming [McCallum et al., 1976] and Rathbun Lake, Ontario [Dressler, 1982]) and that highly saline fluids played an important role in the formation of some deposits (e.g., Pt-rich dunite pipes, Bushveld Intrusion [Schiffries, 1982; Stumpfl and Rucklidge, 1982]), it is now apparent that PGE are highly soluble in some fluids.

Barnes et al. (1985) noted that experimental work by Cousins (1973) showed solubility of PGE in aqua regia in the following order: $\mathrm{Ir}<\mathrm{Os}<\mathrm{Ru}<\mathrm{Rh}<\mathrm{Pd}<\mathrm{Pt}$. They argue that $\mathrm{Pt}$, $\mathrm{Pd}$, and $\mathrm{Au}$ enrichments and depletions in metasomatized ultramafic rocks are in keeping with the mobility of these elements in high-carbonate and/or Cl-rich (seawater) solutions. High $\mathrm{Au}$ mobility during seawater alteration of ocean-floor basalt was documented by Keays and Scott (1976) and Hamlyn et al. (1985). High solubility of $\mathrm{Pt}$ and $\mathrm{Rh}$ in alkali-chloride fluids was confirmed in experimental work by Orlova et al. (1987). Rudashevskiy (1987) related $\mathrm{Ru}$ and Os depletion as well as Pt, $\mathrm{Ir}$, and $\mathrm{Rh}$ accumulation in crushed zones of Koryak Uplands ophiolites (USSR) to the formation of Pt-group secondary minerals in the presence of reducing carbonyl fluids. In summary, all of the noble metals can behave as mobile elements under appropriate conditions.

Like the siderophile and chalcophile elements discussed above, Site 706 noble metal patterns tend to be erratic (Fig. 4), implying that the elements were mobile but that $\mathrm{Rb}$ concentrations act as poor indicators of the degree of alteration of the primary phases that harbor these elements. There is some tendency for $\mathrm{Au}$ and $\mathrm{Pt}$ to show trends with positive slopes whereas $\mathrm{Ir}$ appears to have been removed. By geochemical association, it might be predicted that $\mathrm{Pd}$ and $\mathrm{Rh}$ were added and $\mathrm{Ru}$ removed. It is important to point out that the additions and subtractions for these elements are small such that absolute concentrations for the most part reflect primary values.
The chemical additions expected in the low-temperature area of alteration are especially well represented in Site 706 basalts. It appears likely that the abundance of glass and metastable, quenched minerals in these pillow basalts played an important role in producing the rather large observed additions. Various studies (e.g., Melson, 1973; Thompson, 1973) have shown that glasses exhibit much more exaggerated chemical alteration effects than crystalline basalt. The unstable glass reacts readily with passing solutions, releasing mobile elements into solution. The glass probably plays a critical role in providing such chemical constituents as $\mathrm{Al}$, which are largely immobile in the lowtemperature environment but which are necessary for the formation of zeolite facies minerals such as those observed in Site 706 basalts.

\section{ACKNOWLEDGMENTS}

We wish to acknowledge the support and assistance of all persons in the Ocean Drilling Program who made our participation and the acquisition of samples possible. H. Longerich, S. Jackson, and W. Gosse carried out the noble metal and trace element analyses, and B. Webb prepared the figures. We thank W. Seyfried and one anonymous reviewer, both of whom provided useful comments. This research was supported by a Collaborative Special Projects grant to the authors from NSERC.

\section{REFERENCES}

Alt, J. C., Honnorez, J., Laverne, C., and Emmermann, R., 1986. Hydrothermal alteration of a 1-km section through the upper oceanic crust, Deep Sea Drilling Project Hole 504B: mineralogy, chemistry, and evolution of seawater-basalt interactions. J. Geophys. Res., 91: 10,309-10,335.

Backman, J., Duncan, R. A., et al., 1988. Proc. ODP, Init. Repts., 115: College Station, TX (Ocean Drilling Program).

Barnes, S.-J., Naldrett, A. J., and Gorton, M. P., 1985. The origin of the fractionation of platinum group elements in terrestrial magmas. Chem. Geol., 53:303-323.

Basaltic Volcanism Study Project, 1981. Basaltic Volcanism on the Terrestrial Planets: New York (Pergamon Press).

Cousins, C. A., 1973. Notes on the geochemistry of the platinum group elements. Trans. Geol. Soc. S. Afr., 76:77-81.

Dressler, B. O., 1982. Geology of the Wanapitei Lake area, District of Sudbury. Ont. Geol. Surv., Rep. No. 213, incl. maps 2450 and 2451.

Duncan, R. A., Backman, J., and the Shipboard Scientific Party, 1989 Réunion hotspot activity through Tertiary time: initial results from the Ocean Drilling Program, Leg 115. J. Volcanol. Geotherm. Res., 36:193-198.

Fisk, M. R., Baxter, A. N., Duncan, R. A., Greenough, J. D., Hargraves, R. B., and Tatsumi, Y., 1989. Deccan-Réunion hotspot magma chemistry over the past 65 m.y.: results from Leg 115 of the Ocean Drilling Program. Geology, 17:934-937.

Floyd, P. A., 1977. Rare earth element mobility and geochemical characterization of spilitic rocks. Nature, 269:134-137.

Floyd, P. A., and Winchester, J. A., 1975. Magma type and tectonic setting discrimination using immobile elements. Earth Planet. Sci. Lett., 27:211-218.

Frey, F. A., Bryan, W. B., and Thompson, G., 1974. Atlantic Ocean floor: geochemistry and petrology of basalts from Legs 2 and 3 of the Deep Sea Drilling Project. J. Geophys. Res., 79:5507-5527.

Gillis, K. M., and Robinson, P. T., 1985. Low-temperature alteration of the extrusive sequence, Troodos ophiolite, Cyprus. Can. Mineral., 23:431-441.

1988. Distribution of alteration zones in the upper oceanic crust. Geology, 16: 262-266.

in press. Alteration of the ICRDG CY-1 and CY-1A drill cores, Troodos ophiolite: mineralogical and geochemical studies. Init. Repts. of the I.C.R.D.G., Vols. CY1 and CY-1A.

Greenough, J. D., and Papezik, V. S., 1985. Chloritization and carbonatization of Cambrian volcanic rocks in eastern Newfoundland and southern New Brunswick. Chem. Geol., 53:53-70.

Gresens, R. L., 1967. Composition-volume relationships of metasomatism. Chem. Geol., 2:47-65. 
Hall, J. M.; and Robinson, P. T., 1979. Deep crustal drilling in the North Atlantic Ocean. Science, 204:573-586.

Hamlyn, P. R., Keays, R. R., Cameron, W. E., Crawford, A. J., and Waldron, H. M., 1985. Precious metals in magnesian low-Ti lavas: implications for metallogenesis and sulfur saturation in primary magmas. Geochim. Cosmochim. Acta, 49:1797-1811.

Hellman, P. L., Smith, R. E., and Henderson, P., 1979. The mobility of the rare earth elements: evidence and implications from selected terrains affected by burial metamorphism. Contrib. Mineral. Petrol., $71: 23-44$.

Humphris, S. E., and Thompson, G., 1978. Hydrothermal alteration of oceanic basalts by seawater. Geochim. Cosmochim. Acta, 42:107-125.

Hynes, A., 1980. Carbonatization and mobility of $\mathrm{Ti}, \mathrm{Y}$, and $\mathrm{Zr}$, in Ascot Formation metabasalts, southeast Quebec. Contrib. Mineral. Petrol., 75:79-87.

Keays, R. R., and Scott, R. B., 1976. Precious metals in ocean-ridge basalts: implications for basalts as source rocks for gold mineralization. Econ. Geol., 71:705-720.

McCallum, M. E., Loucks, R. R., Carlson, R. R., Cooley, E. F., and Doerge, T. A., 1976. Platinum metals associated with hydrothermal copper ores of the New Rambler Mine, Medicine Bow Mountains, Wyoming. Econ. Geol., 71:1429-1450.

Melson, W. G., 1973. Basaltic glasses from the Deep Sea Drilling Project, chemical characteristics, compositions of alteration products, and fission track "ages." Eos, 54(11):1011-1014.

Morton, J. L., and Sleep, N. H., 1985. A mid-ocean ridge thermal model: constraints on the volume of axial hydrothermal heat flux. $J$. Geophys. Res., 90:11,345-11,353.

Mottl, M. J., 1983. Metabasalts, axial hot springs, and structure of hydrothermal systems at mid-ocean ridges. Geol. Soc. Am. Bull., 94: 161-180.

Mottl, M. J., and Holland, H. D., 1978. Chemical exchange during hydrothermal alteration of basalt by seawater-I. Experimental results for major and minor components of seawater. Geochim. Cosmochim. Acta, 42:1103-1115.

Mottl, M. J., Holland, H. D., and Corr, R. F., 1979. Chemical exchange during hydrothermal alteration of basalt by seawater-II. Experimental results for $\mathrm{Fe}, \mathrm{Mn}$ and sulfur species. Geochim. Cosmochim. Acta, 43:869-884.

Nyström, J. O., 1984. Rare earth element mobility in vesicular lava during low-grade metamorphism. Contrib. Mineral. Petrol., 88:328-331.

Orlova, G. P., Yevstigneyeva, T. L., Ryabchikov, I. D., and Muravitskaya, G. N., 1987. The behaviour of platinum and rhodium during copper sulfide crystallization under hydrothermal conditions. Geochem. Int., 24:118-121. [Transl. from Geokhimiya, 1986, 12:17921796.]

Oshin, I. O., and Crocket, J. H., 1982. Noble metals in Thetford Mines ophiolites, Quebec, Canada. Part I: Distribution of gold, iridium, platinum, and palladium in the ultramafic and gabbroic rocks. Econ. Geol., 77:1556-1570.

Papezik, V. S., Greenough, J. D., Colwell, J. A., and Mallinson, T. J., 1988. North Mountain basalt from Digby, Nova Scotia: models for a fissure eruption from stratigraphy and petrochemistry. Can. J. Earth Sci., 25:74-83.

Pearce, J. A., and Cann, J. R., 1973. Tectonic setting of basic volcanic rocks determined using trace element analyses. Earth Planet. Sci. Lett., 19:290-300.

Rona, P. A., 1984. Hydrothermal mineralization at seafloor spreading centers. Earth-Sci. Rev., 20:1-104.

1988. Hydrothermal mineralization at oceanic ridges. Can. Mineral., 26:431-465.

Rudashevskiy, N. S., 1987. Origin of the various types of platinoid mineralization in ultramafic rocks. Int. Geol. Rev., 29:465-480. [Transl. from Zap. Vseross. Mineral., 1987, 116(2):222-238.]

Schiffries, C. M., 1982. The petrogenesis of a platiniferous dunite pipe in the Bushveld Complex: infiltration of a chloride-rich solution. Econ. Geol., 77:1439-1453.

Seyfried, W. E., Jr., Berndt, M. E., and Seewald, J. S., 1988. Hydrothermal alteration processes at mid-ocean ridges: constraints from diabase alteration experiments, hot-spring fluids and composition of the oceanic crust. Can. Mineral., 26:787-804.

Stumpfl, E. F., and Rucklidge, J. C., 1982. The platiniferous dunite pipes of the eastern Bushveld. Econ. Geol., 77:1419-1431.

Thompson, G., 1973. A geochemical study of the low-temperature interaction of seawater and oceanic igneous rocks. Eos, 54(11):10151018.

Watkinson, D. H., and Dunning, D., 1979. Geology and platinumgroup mineralization, Lac-des-Iles complex, northwestern Ontario. Can. Mineral., 17:453-462.

Winchester, J. A., and Floyd, P. A., 1977. Geochemical discrimination of different magma series and their differentiation products using immobile elements. Chem. Geol., 20:325-343.

Date of initial receipt: 1 February 1989

Date of acceptance: 11 September 1989

Ms 115B-129 